Financial Markets, Institutions and Risks, Volume 3, Issue 1, 2019 ISSN (online) - 2521-1242 ISSN (print) - 2521-1250

\title{
Effect of Capital Adequacy, Credit Risk and Operating Efficiency on the performance of Commercial Banks in Nigeria
}

http://doi.org/10.21272/fmir.3(1).106-114.2019

\section{Innocent Idachaba Odekina}

MSc, Department of Banking and Finance, Faculty of Administration, Ahmadu Bello University, Nigeria

Ademola Olukotun Gabriel

$\mathrm{PhD}$, Department of Banking and Finance, Faculty of Management Sciences, Kogi State University, Nigeria

Teryima Torlagh Solomon

MSc, Department of Banking and Finance, Faculty of Administration, Ahmadu Bello University, Nigeria

\begin{abstract}
The examination of determinants of banks' profitability has attracted great attention in the developed and developing economies, particularly in the area of business and corporate finance literature. This is because, profitability is an issue of great concern to shareholders and other corporate stakeholders. The need to improve banking institutions in Nigeria became imperative for better profitability of the banking industry in the region. This paper examined the effect of capital adequacy, credit risk and operating efficiency on the performance of commercial banks in Nigeria. The study used secondary panel data sourced from the CBN and Annual Bank Reports. The data analysis technique employed is panel random effect regression method. The capital adequacy variables of the study show that capital adequacy have significant positive effect on the bank's financial performance. However, credit risk, and operating efficiency have negative and statistically significant effect on the financial performance of the banks in Nigeria. It concludes that capital adequacy strongly and actively stimulates, improve and grow the financial performance of commercial banks and that sufficiency of capital and adequate management can translate to improved performance. Based on the findings, the study recommends for improvement in the management of bank assets and liabilities, especially on the quality of assets portfolio and deposit liabilities in order to improve on the achievement of corporate objectives, and for the corporate governance process to be enhanced by adopting international best practices. The regulatory framework should also be enhanced to be more dynamic and effective as this will impact positively on bank management and enhance financial performance of commercial banks in Nigeria.
\end{abstract}

Keywords: financial institution, capital adequacy, profitability, bank failure, credit risk, operational efficiency.

JEL Classification: G2, G21.

Cite as: Innocent Id. Od., Ademola Ol. G., Teryima T. S. (2019). Effect of Capital Adequacy, Credit Risk and Operating Efficiency on the performance of Commercial Banks in Nigeria. Financial Markets, Institutions and Risks, 3(1), 106-114. http://doi.org/10.21272/fmir.3(1).92-114.2019.

(C) The Authors, 2019. This article is published with open access at Sumy State University.

\section{Introduction}

\subsection{Background to the Study}

The examination of determinants of banks' profitability has attracted great attention in the developed and developing economies, particularly in the area of business and corporate finance literature. This is because, profitability is an issue of great concern to shareholders and other corporate stakeholders. The need to improve banking institutions in Nigeria became imperative for better profitability of the banking industry in the region (Obienusi 2015). However, issues of capital inadequacy, operational inefficiency, and credit risk in terms of low profit margins and inflated overhead costs, risk management and heaps of non-performing loans as well as corporate governance may pose significant threat to the banking sector (Sanusi 2010).

Previous studies opined that factors such as capital adequacy, credit risk, and operational efficiency of the bank could have effect on banks' profitability because they are considered as bank-specific factors that are associated with banks' risk and operational management. Possible sources of bank failures such as capital inadequacy, operational inefficiency, high nonperforming loans, and poor regulations problems have therefore attracted great attention from researchers to investigate their impact on profitability of banks. 
Financial Markets, Institutions and Risks, Volume 3, Issue 1, 2019 ISSN (online) - 2521-1242 ISSN (print) - 2521-1250

Capital adequacy serves as a safety net in case of any eventuality. Its high ratio implies lower external financing and subsequently, higher profitability. It enables a bank's ability to retain capital, absorb loan losses, support future growth of assets and provide return to investors, (Qin \& Pastory, 2012). When the ratio is high, it is expected that the requirement for external finance will reduce, thereby leading to higher bank profitability, (Johannes, 2015). Highly capitalized banks are found to be more profitable than poorly capitalized ones because they incur less bankruptcy costs and less requirement for external financing particularly in developing economies, (Almazari, 2013).

Additionally, credit risk, represented by nonperforming loans ratio is another important determinant of bank profitability. Nonperforming loans is the loans that are in existence for a minimum period of 90 days whose the buyer fail to repay the principal are interest due on the loans (Basel, 2001). Commercial Banks are expected to be prepared for any likely shock, emanated from credit risk by having higher provision or reserve for likely loan defaults. This is because, the higher the value of the provision for loan losses, the lower the effect of the shock from uncollectible loans or credits because bad loans tend to reduce bank profitability. Furthermore, Operational efficiency is a significant determinant of bank profitability. Regarding the variable, the Passthrough Hypothesis of Maudos \& Solis (2009) states that banks can transfer or pass their operating expenses to their customers. It is anticipated that a higher level of return on assets (ROA) will arise from a bank's transfer of its higher level of operating costs to its depositors and lenders, indicating a positive relationship between operating costs and bank profitability. Similarly, the efficiency Hypothesis predicts that a bank with lower operational expenses and more efficient operation than its competitors, subsequently benefits from higher profitability. However, in spite of the lofty contribution of banking industry to the growth of trade, manufacturing industry, Information and Communication Technology, agriculture among others, leading to more production and employment, the sector has severally witnessed chronic illiquidity, technical insolvency, poor capital base, weak corporate governance, poor asset quality and so on, (Ojong, Ekpuk, Ogar \& Emori 2014). The incessant bank distress in Nigeria could be attributed to weak financial intermediation capacity of the banking sector, (Konboye \& Nteegah 2016). For example, the bank failures occurred as a result of inefficiency of the management and high risk of capital exposure, (Olukotun, Olusegun \& Olorunfemi 2013). The banks' collapse may be perhaps due to operational inefficiency, capital inadequacy, inexperienced personnel, huge non-performing loans, absence of banking regulations and prudential guidelines among others. Consequently, the depositors suffered massive losses, leading to loss of confidence in the banking system. Also, in 2017, issues of capital inefficiency, operational inefficiency in terms of low profit margins and inflated overhead costs, risk management and heaps of non-performing loans as well as corporate governance problems were debatably common and resulted to takeover or sales of Diamond and skye banks in Nigeria.

Given this backdrop, many studies have established convergency relationship between banks profitability and banks internal factors (Ifuero \& Michael 2014; Ayanda, Christopher \& Mudashiru, 2013). The studies had envisaged to fill many theoretical gaps in the literature that established relationship between internal factors and profitability of firms. Firstly, there had been inconsistent mixed result on the relationship between internal factors and firm profitability. Some studies report positive relationship while others reported negative relationship. Hence, the need to re- investigate the contradictory findings. Secondly, most of prior studies had a random application or misapplication of these variables (factors). Thirdly, majority of the studies on this relationship was on the non-banking context. Very few were on banking sector of other countries. Fourthly, among researchers (Olanrewaju 2016), (Samad 2015), (Sreesha 2014), (Almazari 2014) among others), emphasis has been on the merit of including operational efficiency when assessing internal factors affecting bank profitability. Examining the role of this variable in relation to performance, particularly in Nigeria is relevant. This is because it may explain the reason why banks failure are frequent (if it does not explain profitability) because the literature provides that operational efficiency impacts positively on corporate performance. It is in this regard that the present study deems it fit to explore this relationship in order to reveal whether it drives profitability of banks in these jurisdictions.

This study is also intending to address some methodological gaps. For example, studies like Adegboye, Olowe and Uwuigbe (2013) and Ifuero \& Michael (2014) applied Ordinary Least Square (OLS) when assessing the determinants of bank performance in Nigeria. In the same vein, Olanrewaju (2015) and Anarfi, Abakah \& Boateng (2016) among others used fixed effect (FE) model in investigating determinants of bank profitability in Nigeria and Ghana respectively. These techniques are argued to be inefficient and produce a bias estimates of the variables of study. For example, the ordinary least square could be very sensitive to the presence of unusual data points in the data used to fit a model because one or two outliers could skew the results of OLS 
Financial Markets, Institutions and Risks, Volume 3, Issue 1, 2019

ISSN (online) - 2521-1242 ISSN (print) - 2521-1250

analysis, which consequently leads to model validation. Also, employing OLS to analyze repeated measures data is not appropriate when the covariance structure is not known to be compound symmetric (Ugrinowitsch, Fellingham \& Ricard, 2004). Their study then established that the application of OLS algorithms to analyze repeated measures data should be limited to cases where a Compound Symmetric(CS) covariance structure is known to be present.i.e. a situation where data sets are balanced.

\subsection{Research Questions}

In order to address problem of this study, the following questions were asked:

Does capital adequacy has effect on the financial performance of listed commercial banks in Nigeria?

$>$ Does operating efficiency has effect on the financial performance of listed commercial banks in Nigeria?

$>$ Does credit risk affect financial performance of listed commercial banks in Nigeria?.

\subsection{Objectives of the Study}

The broad objective of this study is to investigate the effect of capital adequacy, operating efficiency and credit risk on the financial performance of listed commercial banks in Nigeria. speficically, the study seek to;

Investigate the effect of capital adequacy on the financial performance of commercial banks in Nigeria;

Examine the effect of operating efficiency on the financial performance of listed commercial banks in Nigeria;

Examine the effect of credit risk on the financial performance of listed commercial banks in Nigeria.

\subsection{Research Hypotheses}

$\mathrm{H}_{01}$ : Capital adequacy has no significant effect on the financial performance of listed ommercial banks in Nigeria.

$\mathrm{H}_{02}$ : Operating efficiency has no significant effect on the financial performance of listed commercial banks in Nigeria.

$\mathrm{H}_{03}$ : Credit risk has no significant effect on the financial performance of listed commercial banks in Nigeria.

\section{Literature Review}

This section deals with the review of literature related to effect of capital adequacy, credit risk and operating efficiency on the performance of commercial banks in Nigeria. The reviews consist of conceptual review, empirical review and theoretical review.

\subsection{Conceptual Review}

\subsubsection{Concept of Bank Financial Performance}

Financial performance is defined as the outcome of how well assets of a firm are utilized to generate income. It is a yardstick applied to measure the financial health of a firm over a given period of time (Heng \& San, 2011). Financial performance in a broader sense refers to the degree to which financial objectives being or has been accomplished and is an important aspect of finance risk management. It is the process of measuring the results of a firm's policies and operations in monetary terms it is used to measure firm's overall financial health over a given period of time and can also be used to compare similar firms across the same industries or sectors in aggregation. Louri (2005) opined that financial measurement is one of the tools which indicate the financial strengths, weakness, opportunities and threats. These financial measurements according to them include return on investment (ROI), residual income (RI), earnings per share (EPS), dividend yield, price earnings ratio (PER), book value per share. Etc. However, the most commonly used performance measure proxies are return on asset (ROA), return on equity (ROE) or return on investment (ROI). These performance measures proxies are termed as accounting measures. In this study finnancial performance would be measure using return on asset.

\subsubsection{Concept of Capital Adequacy}

Ebhodaghe (1991) defines capital adequacy as a situation where the adjusted capital is sufficient to absorb all losses and cover fixed assets of the bank leaving a comfortable surplus for the current operation and future expansion. Functionally, adequate capital is regarded as the amount of capital that can effectively discharge the primary function of preventing bank failures by absorbing losses. Capital adequacy by definition is seen 
as a quantum of fund, which a financial institution should have and plan to maintain in order to conduct its business in a prudent manner (Kishore 2005). Adequate capital is regarded as the amount of capital that can effectively discharge the primary function of preventing banking industries failure by absorbing losses. It is seen as a way of providing the ultimate protection against insolvency arising from the risk in banking sector. It is the least amount necessary to inspire and sustain confidence in the banks, keep it open and operating so that time and earnings can absorb losses without being forced into costly liquidation and enable banking industry to take full advantage of its profitable growth opportunities (Akintoye \& Somoye 2008). It is to be expected that firm value can be enhanced by judicious use of equity and borrowed capital. Crosse and Hamsel (1980) state that capital has to do with the bank's ability to generate income and a means for expanding its operations, deliver quality service and hence remain competitive.

\subsubsection{Concept of Operating Efficiency}

According Anderson and Lanen, (2009) Operational cost efficiency measures how much it is expensive for the bank operating in order to produce per unit of output. High total cost to total income ratio causes the lower profitability for the banks and low of the ratio shows the increase in the profit. Operational cost efficiency is computed as a ratio of total cost to total income.

\subsubsection{Concept of Credit Risk}

Risk management is one of the most important activities in any banks and cannot be overlooked by any economic enterprise engaged in credit irrespective of its business nature. Sound credit management is a prerequisite for a financial institution's stability and continuing profitability, while deteriorating credit quality is the most frequent cause of poor financial performance and condition. As with any financial institution, the biggest risk in bank is lending money and not getting it back (Kagoyire \& Shukla, 2016). Credit risk involve the loss or damage that may arise as result of the credit transaction of the banks. As a result of the nature of the banking business credit risk constitute the major form of risk that banks are expose to in Nigeria (Maxwel \& Peter, 2016). Credit risk arises whenever a lender is exposed to loss from a borrower, counterparty, or an obligator who fails to honour their debt obligation as they have contracted (Luy, 2010). According to Colquitt (2007), this loss may derive from deterioration in the counterparty's credit quality, which consequently leads to a loss to the value of the debt, or according to Crouhy, et al., (2006), the borrower defaults when he is willingly to fulfill the obligations. Credit risk is one of the major risk that bank financial institution expose to due to the form of their operations. In this study credit risk will be proxy with nonperforming loans and capital adequacy ratio (Duffie \& Singleton, 2012). Nonperforming loans are loans that are in existence for a minimum period of 90 days whose the buyer of the loans are yet to pay either principal or interest due on the loans. A high NPL ratio requires greater loan loss provisions, reducing capital resources available for lending and denting bank profitability. For a debtor, an NPL traps valuable collateral and the unresolved debt makes it more difficult to obtain new funding and make investment (Bernanke et al., 1999). Also it capable of affecting the financial performance of the banks.

\subsection{Review of Related Studies}

Adeyinka (2013) examine the effect of capital adequacy on profitability of deposit-taking banks in Nigeria. It seeks to assess the effect of capital adequacy of both foreign and domestic banks in Nigeria and their profitability. The study made use of secondary data covered period of 2006 to 2010 . The study found positive relationship between capital adequacy and banks performance. The finding did not reflect current state of Nigeria banking industry. Also, Onaolapo and Olufemi (2012) examine the effects of capital adequacy conditionality on the performance of selected banks within the Nigerian banking sector. Data employed are mainly secondary and were obtained from the publications of regulatory agencies like the Central Bank of Nigeria in a ten-year period 1999-2008. The study made use of secondary source of data. Multiple regression was used to analysis the data. Findings indicate that all the performance indicators tested such as Returns on Assets (ROA), Returns on Capital Employed (ROCE) and Efficiency Ratios (ER) among others do not reflect much on Capital Adequacy Ratio (CAR) of the Nigerian banking sector. Goddard (2004) investigates profitability of European banks using cross sectional data during 1990s. The results show that the relationship between the capital to asset ratio and profitability is positive. Athanasoglou (2005) examines the effect of bank specific, industry specific and macroeconomic determinants of bank profitability. The coefficient of capital variable is positive and highly significant reflecting the sound financial condition of Greek banks. Onoalapo and Olufemi (2012) study reveal that, capital adequacy ratio did not reflect the profitability of banks represented by Return on Assets, Return on Capital Employed and Percentage of Profit before Tax. Similarly, Santos (2000) asserts that bank regulation through higher capital requirements negatively affect bank 
Financial Markets, Institutions and Risks, Volume 3, Issue 1, 2019 ISSN (online) - 2521-1242 ISSN (print) - 2521-1250

development and credit expansion by increasing fixed and operating costs. However, Ezike and Oke (2013) study shows that capital adequacy proxied by Shareholders Fund exert positive influence on banks' profit, total assets, total deposits, return on assets, earnings per share, loans and advances and credit risk, although not all were statistically significant.

Using cross sectional and time series of bank data and employing the OLS regression method, Ikpefan (2015) determined the impact of bank capital adequacy ratios, management and performance in the Nigerian commercial banks. The study shared that Shareholders Fund/Total Assets which measures capital adequacy (risk of default) have negative impact on Return on Assets. The efficiency of management measured by operational expenses indices is negatively related to return on capital.

Ayayalin and Karakaya (2014) applied the two step system generalized method of moment technique for dynamic panel using bank level date for Turkish banking sector over the period 2003 to 2011, to investigate the impact of banks' capital on profitability and risk. The study found evidence that there is a positive relationship between capital and profitability. The study document negative relationship between operating efficiency and banks performance. Ejoh and Iwara (2014) assessed the impact of capital adequacy on deposit money banks' profitability in Nigeria for the period 1981-2011 on five selected banks. The study shows that capital adequacy plays an important role in explaining bank returns on assets (ROA) which is a measure of bank profitability.

Evidenced from literature review showed that there is divergence in previous studies. Althrough of the studies conducted outside Nigeria confirm the importance of bank level factors such as; capital adequacy, operational efficiency, and credit risk on bank performance. However, outcome of these studies may not be applicable in Nigeria because there is differences in financial, economic, politcal and socio-cultural factors of those countries and Nigeria. On the other hand, those studies that were conducted in Nigeria, failed to captured recent risk and banks failures (Diamond and Skye banks)that may likely affect financial performance. On this ground, this study would provides additional knowledge about Nigeria commercial banking sector that is important for policy making.

\subsection{Theoretical Framework}

This part covers the theoretical underpinnings that the study is based. It establishes divergent theories from which the study is rooted.

Buffer Theory of Capital Adequacy: Banks may prefer to hold a 'buffer" of excess capital to reduce the probability of falling under the legal capital requirements, especially if their capital adequacy ratio is very volatile. Capital requirements constitute the main banking supervisory instrument in Nigeria. The Central Bank of Nigeria $(\mathrm{CBN})$ intervenes little in banks' activities but does directly conduct on-site examination and at times delegating this task to external auditors. By contrast, a breach of the capital requirements is considered a major infringement of banking legislation and is not tolerated by the Central Bank of Nigeria (CBN). The buffer theory of Calem and Rob (1996) predicts that a bank approaching the regulatory minimum capital ratio may have an incentive to boost capital and reduce risk in order to avoid the regulatory costs triggered by a breach of the capital requirements. However, poorly capitalized banks may also be tempted to take more risk in the hope that higher expected returns will help them to increase their capital. This is one of the ways risks relating to lower capital adequacy affects banking operations.

Expense Theory: According to the expense theory of Williamson (1963) otherwise called the theory of managerial discretion, managers have the option in pursuing policies, which maximize their own utility rather than profit maximization for shareholders. Such utility includes the satisfaction which managers derive from certain types of expenditure. Managers' prestige, power and status are to some extent reflected in the amount of slack they receive in the form of expense account, luxurious offices and building, company cars and other perquisites of office. Operating efficiency attempts to capture this aspect of bank behaviour. Operating expenses is derived from the use of resources and can have positive or negative implication on the dependent variable. Considering the above theoretical bases, the study adopts the Buffer Theory of Capital Adequacy and expense theory which coincides with the findings of the study.

\subsection{Methodology}

This section addresses the design strategy to be used, the study unit, who or what forms the population of the study, whether sampling will be done and if so the sampling design to be used and the sample size. It also shows the kind of data to be used, where or from whom it will be collected and the instrument that will be used and how the researcher will reach respondents or data source. Finally it explains on how the data collected 
will be analyzed and presented. The study employs descriptive research design using panel data of ten years (2008-2017). The population of this study consisted 14 listed commercial banks in Nigeria. However, due to small size of the population, census was taken to select all the population as sample size for this study.

To investigate the impact of independent variables (capital adequacy, credit risk, and operating efficiency) on the dependent variables (financial performance), a modified model of was adopted. A regression of a variable, $\mathrm{Y}$ on $\mathrm{X}$ is an equation model that expresses the influence of $\mathrm{Y}$ (the dependent variable) on $\mathrm{X}$ (the independent).

Symbolically, the linear regression is:

$\mathrm{Y}=F(\mathrm{X})$ that is, $\mathrm{Y}$ is a function of $\mathrm{X}$;

$\mathrm{Y}=0+1 \mathrm{X}_{1}+2 \mathrm{X}_{2}+\ldots \ldots+\mathrm{nXn}+\mu$

Where,

$\mathrm{Y}=$ the dependent variable (financial performance)

$\mathrm{X}=$ the independent variable

$0=$ the intercept, that is, the value of the dependent variable $Y$, when the explanatory variable

$\mathrm{X}$ assumes a value of zero.

$1 \ldots . . . n=$ coefficient of the explanatory variables or the slope, that is, the rate at which a change in the explanatory variable affects the behaviour of the dependent variable and $\mu$ is the error term.

The mathematical form of the model is specified in a functional relationship as follows; The linear regression equation based on the above functional relation for the model is econometrically stated as:

$\mathrm{ROA}=\alpha+\beta_{1} \mathrm{CAR}_{\mathrm{it}}+\beta_{2} \mathrm{CAR}_{\mathrm{it}}+\beta_{3} \mathrm{CAR}_{\mathrm{it}}+\mu_{\mathrm{it}}$

Where, $\mu, \mathrm{ROA}=$ Return on Assets, $\mathrm{CAR}=$ Capital Adequacy, $\mathrm{NPL}=$ Nonperforming loans, $\mathrm{OPR}=$ Operating Efficiency

$\alpha$ is constant, $\beta$ is slope of the regression and $\mu$ is error term. Thus, capital adequacy is proxied by capital to risk weighted assets, Profitability by profit after tax to total assets, operating efficiency by operating expenses to total asset, and nonperforming loans by nonperforming loans to gross loans.

\subsection{Result and Discussions}

Table 1. Summary of Diagnostics Test

\begin{tabular}{|c|c|c|}
\hline Test Specification & Chi2 & P-value \\
\hline Normality Test (Shapiro-Wilk W test for normal data) & & 0.51927 \\
\hline Multicoliarity Test (VIF) & & \\
\hline Model Specification Test (Ramsey RESET test) & 0.83 & 0.7201 \\
\hline (Breusch-Pagan / Cook-Weisberg test for heteroskedasticity) & 0.53 & 0.8667 \\
\hline Hausman Specification Test & 2.33 & 0.5070 \\
\hline Breusch-Godfrey test langranger Multiplier test of Random Effect & 13.82 & 0.0000 \\
\hline
\end{tabular}

Source: Authors' calculation 2019.

The summary of diagnostic test was presented on table 1. Shapiro-Wilk test of normality was further carried out to check for normality of the study data, the $\mathrm{p}$-value $(0.51927)$ of Shapiro test was greater than $5 \%$ critical level, meaning that the null hypothesis that the residual was not normally distributed was rejected. The study concluded that data were normally distributed and it seemed that the error term in all of the cases followed the normal distribution.

Value of variance inflation $f$ actor (VIF) was less than 10 and tolerance value was greater than 0.10 , this indicated the absence of multicollinearity in the study independent variables. The result showed that, no multicollinearity problem existed since VIF was less than 10 and $1 / \mathrm{VIF}$ is greater than 0.1 . Test of heteroskedasticity was carried out using Breusch-Pagan/Cook-Weisberg test for heteroskedasticity to check for the homoscedaticity/heteroscedaticity of the errors across the residuals. The result p-value 0.8667 was greater than 5\% significance level. This implied that there was evidence for the absence of heteroscedasticity. The study therefore rejected the null hypothesis of heteroscedasticity. The study made use of Ramsey reset (1969), to check for the presence of omitted or additional variable in the model specification, the result showed 
Financial Markets, Institutions and Risks, Volume 3, Issue 1, 2019 ISSN (online) - 2521-1242 ISSN (print) - 2521-1250

that there was no presence of model specification error given the p-value of 0.7201 greather that $5 \%$ significance level. this shows that the study model is correctly specified.

Hausman specification test (1978) was further carried out to choose appropriate model between random and fixed effect model. The result showed that there was constant error variation across the panel given the $p$ value 0.5070 greater than $5 \%$ critical level. This implied variation of error across the panel were constant. Hence, random effect model is appropriate for the study. The study further carried out Breusch-Godfrey serial correlation Lagranger multiplier test of random effect to choose between random and ordinary least square (OLS). The result further proved that random effect is appropriate given the p-value less than $5 \%$ significance level. The result implies that there is panel effect, therefore random effect is appropriate for the study.

Table 2. Panel Random Effect Model Estimate Result

\begin{tabular}{|c|c|c|c|c|}
\hline Variables & Coefficent & Std. err & t-statistic & $\mathrm{p}$-value \\
\hline Constant & 0.0327077 & 0.9149820 & 0.0356 & 0.971 \\
\hline CAR & 0.5810490 & 0.0831482 & 6.9881 & 0.000 \\
\hline NPL & -0.0401044 & 0.0140027 & -2.8640 & 0.004 \\
\hline OPR & -0.1549285 & 0.0138188 & -11.2113 & 0.000 \\
\hline $\begin{array}{lc}\mathrm{R}^{2} \text { Averall } & 0.6559 \\
\text { Waldchi2 } & 455.49 \\
\text { Probability } & 0.0000\end{array}$ & & & & \\
\hline
\end{tabular}

Source: Stata Output 2019.

\subsection{Discussion of findings}

The $\mathrm{R}^{2}$ averall value of 0.6559 or $65.59 \%$ showed that all the study independent variables jointly accounted for about 65.59 variation in the dependent variables, while the remaining $34.41 \%$ were explained by other factors that were not incorporated into the study model. The result further confirm with the value of Wald chi2 of 455.49 with probability value of 0.0000 , significance at $1 \%$ level. This showed that the model is fit and good for the study.

\section{Capital Adequacy and Financial Performance}

The result of our finding in the table 2 shows that capital adequacy has poistive and significant effect on the banks financial performance. This is evidenced from possitive coefficient 0.5810490 with $p$-value 0.000 less than 5\% significance level. This implied that a unit percent increase in the CAR of bank will bring about $58.10 \%$ increase in the banks financial performance. The study therefore fail to accept null hypothesis that capital adequacy has no significant effect on the banks financial performance in Nigeria. This finding is in line with work of Ezike and Oke (2013) who found a positive relationship between capital adequacy and banks financial performance in Nigeria. however, the finding is not inline with result of Onoalapo and Olufemi (2012) who document insignificant effect of capital adequacy on banks performance.

\section{Credit Risk and Financial Performance}

Furthermore, the coefficient (-0.0401044) of credit risk proxy by nonperforming loans showed a negative and significant effect on banks financial performance. This finding revealed that a unit percent rise in value of bank NPL will bring about $4.01 \%$ decrease in the banks financial performance in Nigeria. This finding signify that nonperforming loans affect ability of the banks to generate more income through loans and advance, which may decrease their financial performance. Based on this finding, the study fail to accept null hypothesis that credit risk has no significant effect on the banks financial performance in Nigeria. the outcome support finding of Torbira and Zaagha, (2016) who document negatve and significant relationship between credit risk and banks financial performance.

\section{Operating Efficiency and Financial Performance}

The result also shows that operating efficiciency has negative and significant effect on the banks financial performance. This is evidenced from negative coefficient of -0.1549285 and p-value of 0.000 less than $5 \%$ significance level. this finding reveals that for every successful unit increase in operating expenses will bring about $15.49 \%$ decrease in the banks financial performance. It can be infer from this finding that expenses incure by the banks contributed to decrease in the banks financial performance. Based on this finding, the study fail to accept null hypothesis that operating efficiency has no significant effect on the banks financial performance. The outcome of this study is in line with work of Onoalapo and Olufemi (2012); Ikpefan (2015); Iwara (2014) who document negative and significant relationship between operating efficiency and banks financial performance. 


\subsection{Conclusion and Recommendations}

In the light of the findings of this study, the study concludes that, the impact of capital adequacy, credit risk, and operating expenses on the financial performance of quoted banks in Nigeria is statistically significant. This implies that financial performance in terms of profitability and customers' deposits are majorly influenced by capital adequacy, operating expenses and credit risk. It means that the various efforts by the monetary authority to review often times the capital base of the banking sector is not borne out of the aim to improve the financial performance of the banks but mainly to maintain stability in the banking industry. This finding informs the study to recommend for pragmatic changes in bank regulatory focus, improved corporate governance, personnel training and stable polity as antidotes for ensuring sound financial health for the Nigerian banking sector. there should be a constant review of the minimum capital requirement of deposit money banks in Nigeria to the optimal level, that Nigerian banks should be well capitalized to enable them enjoy access to cheaper sources of funds with subsequent improvement in profit levels which would help the public maintain confidence in the bank and also accommodate the credit needs of customers.

\section{References}

1. Adegboye, F. B., Olowe, O., \& Uwuigbe, O. R. (2013). Returns on investment of deposit money banks (DMBs) in Nigeria. Journal of Applied Finance \& Banking, 3(3), 195-206.

2. Adeyinka, S. (2013). Capital Adequacy And Banks' Profitability Of Deposit Taking: An Empirical From Nigeria. Far East Journal of Psychology and Business, 13(4), 32-41.

3. Almazari, A. A. (2013). The relationship between working capital management and profitability: Evidence from Saudi cement companies. British Journal of Economics, Management \& Trade, 4(1), 146157.

4. Almazari, A. A. (2014). Impact of internal factors on bank profitability: Comparative study between Saudi Arabia and Jordan. Journal of Applied finance and banking, 4(1), 125.

5. Anarfi, D., Abakah, E. J. A., \& Boateng, E. (2016). Determinants of Bank Profitability in Ghana: New Evidence. Asian Journal of Finance \& Accounting, 8(2), 194-204.

6. Anderson, S. W., \& Dekker, H. C. (2009). Strategic cost management in supply chains, part 2: Executional cost management. Accounting Horizons, 23(3), 289-305.

7. Athanasoglou, P., (2005). Bank-Specific, Industry Specific and Macroeconomic Determinants of Bank Profitability. Journal of International Financial Markets, Institutions and Money, 18(12), 22-35.

8. Ayanda, A. M., Christopher, E. I., \& Mudashiru, M. A. (2013). Determinants of banks' profitability in a developing economy: Evidence from Nigerian banking industry.

9. Ayaydin H and A. Karakaya (2014) Effect of Bank Capital on Profitability and Risk in Turkish Banking, International Journal of Business and Social Science 5(1).

10. Basel Committee. (2001). The new Basel capital accord. Consultative Document, Basle, January.

11. Bernanke, B. S., Gertler, M., \& Gilchrist, S. (1999). The financial accelerator in a quantitative business cycle framework. Handbook of macroeconomics, 1, 1341-1393.

12. Calem, P. S., \& Rob, R. (1996). The impact of capital-based regulation on bank risk-taking: a dynamic model. Division of Research and Statistics, Division of Monetary Affairs, Federal Reserve Board.

13. Colquitt, J. (2007). Credit risk management: How to avoid lending disasters and maximize earnings. McGraw-Hill.

14. Crouhy, M., Galai, D., \& Mark, R. (2006). Risk capital attribution and risk-adjusted performance measurement. In Risk Management, 433-454.

15. Duffie, D., \& Singleton, K. J. (2012). Credit risk: pricing, measurement, and management. Princeton University Press.

16. Ebhodaghe, J. U. (1991). 'Bank deposit insurance scheme in Nigeria'. NDIC Quarterly, 1(1), 17-25.

17. Ezike, J. E., \& MO, O. (2013). Capital adequacy standards, basle accord and bank performance: the nigerian experience (A case study of selected Banks in Nigeria). Asian Economic and Financial Review, $3(2), 146$.

18. Goddard, J., (2004). The profitability of European banks: a cross-sectional and dynamic panel analysis. The Manchester School, 72(3), 363-381.

19. Ifuero, E. O., \& Michael, C. I. (2014). The impact of macroeconomic variables on the profitability of listed commercial banks in Nigeria. European Journal of Accounting Auditing and Finance Research, 2(10), 85-95.

20. Ikpefan, O. A., (2015). Capital Adequacy, Management and Performance in Nigeria Commercial Bank, African Journal of Business Management, 6(1), 65-73. Interdisciplinary Journal of contemporary research in business, 4(9), 155-181. 
Financial Markets, Institutions and Risks, Volume 3, Issue 1, 2019

ISSN (online) - 2521-1242 ISSN (print) - 2521-1250

21. Iwara, U. U. (2014). The Impact of Capital Adequacy on Deposit Money Banks' Profitability in Nigeria. Research Journal of Finance and Accounting ISSN 2222-1697 (Paper) ISSN 2222-2847 (Online), 5(12).

22. Johannes, J. (2015). Incentive pay and bank risk-taking: Evidence from Austrian, German, and Swiss banks. Journal of International Economics, 96, S123-S140.

23. Kagoyire, A., \& Shukla, J. (2016). Effect of credit management on performance of commercial banks in Rwanda (A case study of Equity bank Rwanda LTD). International Journal of Business and Management Review, 4(4), 1-12.

24. Kishore, R. (2005). An analysis of the impact of minimum capital requirements on commercial bank performance in Zimbabwe.

25. Konboye, L. E. J., \& Nteegah, A. Banking Sector Capitalization and Deposit Money Banks' Profitability in Nigeria. International Journal of Social Sciences and Management, 3(3), 203-213.

26. Luori,T. B. (2005). Capital structure and corporate performance of Malaysian construction sector. International Journal of Humanities and Social Science, 1(2), 28-36.

27. Luy, D. L. (2010). Evaluation of credit risk management policies and practices in a Vietnamese jointstock commercial bank's transaction office.

28. Maudos, J., \& Solís, L. (2009). The determinants of net interest income in the Mexican banking system: An integrated model. Journal of Banking \& Finance, 33(10), 1920-1931.

29. Maxwel, M.\& Pater, O. (2016). The Right to Development and Non-State Actors: Rethinking the Meaning, Praxis and Potential of Accountability of Non-State Actors in International Law. Transnat'l Hum. Rts. Rev., 3, 39.

30. Obienusi, I., \& Obienusi, E. A. (2015). Banking reforms and the Nigerian economy, 1990 2007. Historical Research Letter, 21, 17-42.

31. Ojong, Ekpuk, Ogar, O. \& Emori, A.,Y. (2014). G. D. Effects of Recapitalization on Profitability of Quoted Deposit Money Banks in Nigeria. Journal of Accounting and Financial Management ISSN, 4(4), 2018.

32. Olanrewaju, K. (2016). Cutting through the fintech noise: Markers of success, imperatives for banks. Global Banking Practice, McKinsey, New York (December 2015).

33. Olukotun, G. A., \& James, O. O. Olorunfemi Kehinde. (2013). Bank distress in Nigeria and the nigeria deposit insurance. corporation intervention. Global Journal of Management and Business Research Finance, 13(8).

34. Onaolapo, A. A., \& Olufemi, A. E. (2012). Effect of capital adequacy on the profitability of the Nigerian banking sector. Journal of Money, Investment and Banking, 24, 62-72.

35. Qin, X., \& Pastory, D. (2012). Comparative Analysis of Commercial Banks Liquidity Position: The Case of Tanzania. International Journal of business and Management, 7(10), 134.

36. Samad, A. (2015). Determinants bank profitability: Empirical evidence from Bangladesh commercial banks. International journal of financial research, 6(3), 173.

37. San, O. T., Theng, L. L., \& Heng, T. B. (2011). A comparison on efficiency of domestic and foreign banks in Malaysia: A DEA approach. Business Management Dynamics, 1(4), 33-49.

38. Santos, J. A. (2001). Bank capital regulation in contemporary banking theory: A review of the literature. Financial Markets, Institutions \& Instruments, 10(2), 41-84.

39. Shaikh, A., H. (2010). Exploring the nexus between financial sector reforms and the emergence of digital banking culture-Evidences from a developing country. Research in International Business and Finance, 42, 1030-1039.

40. Somoye, R., Akintoye, I., \& Oseni, J. (2008). Asset pricing in an informational inefficient market

41. Sreesha, C. (2014). Efficiency Gains of Bancassurance-Insurance Companies Perspective. International Journal of Research, 1(4), 420-433.

42. Ugrinowitsch, C., Fellingham, G. W., \& Ricard, M. D. (2004). Limitations of ordinary least squares models in analyzing repeated measures data. Medicine \& Science in Sports \& Exercise, 36(12), 21442148.

43. Williamson, O. E. (1963). Managerial discretion and business behavior. The American Economic Review, 53(5), 1032-1057. 